\title{
Institutionalization of Ethical Principles to Overcome Ethical Dilemmas in the Public Sector
}

\author{
I Made Krisnajaya
}

\begin{abstract}
Discussions on public sector ethics essentially cover three main issues. First, how to establish a theoretical argument capable of providing answers to queries about what is considered an ethical and unethical conducts in public sector management. Second, how to develop ethical instruments and standards capable of helping resolve ethical dilemmas that commonly occur in the public sector. Third, how to institutionalize ethical principles and instruments developed in public institutions. Both theoretical studies and empirical experiences indicate that the essence of the various forms of a dilemma in the public sector is the conflict between personal virtue and public virtue. These ethical dilemmas may be subdued by institutionalizing ethical principles in public institutions, and it basically involves two substantial activities, namely integration, and revitalization of ethical principles in public institutions. These ethical principles should be integrated within a system of conducts covering standard values and norms that serve as a reference in conducting oneself and in minimizing unethical conducts and in preventing maladministration in public sector management. Legal instruments remain necessary in order to ensure the effectiveness of ethical principles as a code of conduct for government personnel to carry out their tasks and functions. Of no less importance is the effort to improve leadership that highly reveres ethical principles in the public bureaucracy.
\end{abstract}

\section{Keywords:}

public sector ethics; ethical dilemmas; ethical principles; institutionalization.

\section{Introduction}

The issue of public sector ethics is a subject of discussion that has been summarized in a global dialog (Gilman \& Lewis, 1996, p. 517). Discussions pertaining to the problems of public sector ethics in Indonesia essentially cover three main issues. First, how to establish a theoretical argument capable of the sufficiently providing answer to questions about what is regarded as 'ethical' and 'unethical' conducts in public sector management. Second, how to develop ethical instruments and standards capable of helping resolve ethical dilemmas that commonly occur in public sector management. Third, how to institutionalize ethical principles and instruments developed in public institutions.

The escalating attention on the importance of public sector ethics development has been prompted by at least three factors. Firstly, the global movement of public sector reform, which has begun since the 1980s and has resulted in the rise of various ethical problems aside from success stories in a number of countries. This new management approach dubbed as New Public Management, at a certain level is affected by economic rationalism and public choice theories that idealize more efficient and

\footnotetext{
- Department of Public Policy and Management, Faculty of Social and Political Sciences, Universitas Gadjah Mada Email: imadekrisnajaya2015@gmail.com
} 
result-oriented government management. Such emphasis on efficiency and result orientation has, however, caused ethical problems to arise since in practice those principles were often incompatible, or had even experienced trade-offs, with other prevailing values such as accountability (James, 2003, p. 100).

Secondly, the government experiences deficiencies in numerous fields due to corrupt practices and inefficiencies in public services provision. A government run by inefficient and incompetent human resources is extremely susceptible to various forms of scandals including aberration and misuse of authority. Corruption, collusion, and nepotism (korupsi, kolusi, nepotisme - KKN) are primary forms of such aberration and misuse of authority. Bearing in mind that these scandals may lessen government credibility and lead to the low level of trust society has toward the government, the institutionalization of ethics in the public sector is, thus, an imperative. In other words, the institutionalization of public ethics should become an integral part of "major areas of administrative reform" (Caiden, 1991, p. 101).

Thirdly, government personnel, particularly government officials, are frequently faced with ethical dilemmas while carrying out their tasks and functions. Such ethical dilemmas have even become an inevitability. The political activities occurring in the organizational processes such as resource allocation, decision making, and conflict management often involve unethical conducts that boil down to solely fulfilling narrow group or personal interests. Deceit, manipulation, and other forms of fraud are conducted for the sake of accomplishing group or personal goals by sacrificing public interests. Such misconducts are deemed unethical as one of the policy determinants in the public sector is its consistency with public interests.

This article aims at critically discussing the institutionalization of ethical principles to overcome issues of ethical dilemmas in the Indonesian public sector. The initial part of the article critically discusses the ambivalence of ethics implementation and definition that are dominated by three perspectives namely consequentialism, deontology, and virtue ethics. The second part discusses forms of ethical dilemmas that commonly occur in practices of public bureaucracy management. At the beginning of this section, several distinguishing features between public and private sector management bearing implications on the difference of ethical consideration between the two are briefly discussed. The final part of this article critically discusses the institutionalization of ethical principles to overcome ethical dilemma in the public sector.

\section{Methods}

This study uses literature study in discussing the issues described in this article. The literature studies undertaken include the analysis of literary sources (books, scientific journal articles, labor articles, internet resources, and legal documents) making it possible to present reviews, summaries and analyzes relating to significant aspects of the topics covered.

Based on the analysis and consideration of these literary sources, the author identifies the problematization that focuses on the dynamics of thought thinking about public sector ethics and the implications of dynamic discourse on the interpretation and handling of ethical issues in public sector management. The primary sources of data used in this stage of problematization are books and articles of scientific journals that are thematically researched by considering the relevance and importance of discourse. In the next step, the authors make problematization through descriptive studies to identify the forms and features of ethical dilemmas familiar to the public sector. In the discussion and analysis phase, the authors develop a framework that generates solutions to overcome the ethical 
difficulties in the public sector, which are the focus of discussion in this article.

\section{Results and Discussion}

\section{Ambivalence in Ethics Definition and Implementation}

As a scientific discipline, ethics is one of the branches of axiology that essentially discusses the predicates of 'right' and 'wrong.' Ethics aims to understand and provide explanations on matters involving moral considerations. Therefore, ethics discusses the definition of morality and consideration of right conducts. Ethics basically involves "the effort to guide one's conduct by reason-that is to do what there are the best reasons for doing - while giving equal weight to the best interests of each individual who will be effected by one's conduct" (Grace \& Cohen, 1995, p. 14). This means that ethics is not only integrated into informal and formal rules aimed at regulating or limiting the conduct of man, but it also involves reasoning or rationality that underlies and guides one's conducts in her/his capacity as both an individual and social being.

Epistemologically speaking, ethics can be divided into two kinds that normative ethics and applied ethics. Normative ethics talks about "... what should be done and what should happen, and that allows individuals to determine what is contradictory to what should happen" (Kattsoff, 2004, p. 344). Whereas applied ethics discusses efforts in deciding what is right and what is wrong in actual situations. Applied ethics should not be mixed up with the law. As properly stated in the advisory quote of Baggini (2003), "We may decide that something is right while it is currently illegal or that something is wrong while it is currently legal"(p. 96).

The word ethics has its origin from the Greek ethikos and ethos, which initially referred to "the prevalent sentiment of a people or community" (Ping, 1996, p. 18). Based on this definition, ethics relatively applies within the dimension of time and space. Hence ethics may be differently defined in differing societies. This perspective had even led to what is known as ethical relativism which claims that "there are no universally valid moral principles; the validity of all moral principles is relative to the culture or individual choice" (Shomali, 2001, p. 33). Ethics is relative when consideration of what is deemed to be right or wrong is based on individual preferences or refers to traditional values rooted in society. Ethics involves recognition of conducts that are publicly accepted as wrong or right within a particular society. Hence, norms, traditions, and customs that have been established in society will significantly determine the ethical standards employed in assessing the right and wrong of conduct within the context of the said society.

Nevertheless, ethics also comprises of universally accepted general principles. If certain ethics applies to one case, then it should also apply to the same case happening at different places (Thompson, 1987, p. 105). Ethics becomes a general concept when it is seen as an expression or rationalization of moral principles that must be impartially applied in any given conditions anywhere. It is this very claim that serves as the essential conception of ethical absolutism. Within the frame of universality, ethics is the ideal form of moral argumentation, and it involves moral philosophy that does not reduce ethical choices to based merely on individual preferences (Stewart, 1991, p. 357).

Ambivalence in such ethical definition has serious implications in the long history of the contention of thoughts regarding ethics in both its theoretical and practical dimensions. It is, thus, of no surprise that ethics is regarded as one of the major issues confronted by pioneers of political thoughts since the time of ancient Greece up to the modern era (Schmandt, 2002, p. 7). At a discursive level, 
there are various standpoints on ethics in which among others are ethical formalism, ethical rationalism, ethical relativism, and ethical absolutism. The rise of numerous ethical problems throughout all aspects of human life is thus a logical consequence of the ambivalence in the definition of ethics in itself. An interesting note is that while the contention of thoughts regarding ethics still continues, ethics has manifested into a central issue in nearly all fields of knowledge that have been known throughout man's history.

Theories on ethics may primarily be divided into two categories, namely based on whether the theory considers the means or the ends as the priority (Russell, 2007, p. 241). Based on this distinction, there are at least three prominent perspectives. The first perspective is consequentialism which considers a conduct's right or wrong based on the consequences generated by the said conduct. Moral assessment is based on the logic of consequences, that is the right or wrong of conduct is evaluated based on the extent it generates the desired consequences. Utilitarianism, one of the variants of consequentialism, claims that conducts that are considered as valid are those that generate consequences capable of optimizing the welfare of the society as a whole. However, such perspective does not provide a sufficient argumentation on what consequences are regarded as right and what is regarded as wrong (Preston, 2001, p. 168).

Secondly, the deontology perspectivefrequently referred to as ethical formalism or Kantian ethics - which argues that conduct may be considered right or wrong depending on the nature of the conduct, not on the generated consequences. Morality basically relates to one's conduct that is not result oriented but is influenced by references to rationality and consistency. A person commits to action because it is considered to be right prior to know the consequences of the acts committed. The perspective of deontology in the context of public sector ethics, for instance, refers to "absolute or strict adherence to rules, protocol, and organizational procedures" that is in accordance with the features of Weberian bureaucracy (Alkadry, Blessett \& Patterson, 2015 , p. 1194). In contrast to consequentialism, such normative deontological approach is not always compatible when applied in the political domain. Political activities employ the logic of consequences more than the logic of appropriateness, wherein accomplishing the ends becomes the main priority despite having to use illegal or unethical means.

The third perspective is virtue ethics which is of the view that moral capacity guides individuals to act according to ethical principles. An individual act ethically because she is encouraged by her personal character. Ethics is not merely about what someone should do in his or her personal capacity, but also about how someone should act in one's relation with others (Putnam as cited in Stewart, 1991, p. 357). Good conduct is, thus, one that is carried out by a wise person. The idea of developing a code of ethics for government personnel, for example, is compatible to the perspective of virtue ethics because the ethical standards contained in the code of ethics are representations from expectations of personal characters that should be inherent within the personality of government personnel.

Discussions on ethics, thus, involve cognitive competence that may contradict one another when referring to the appropriate definition either at the normative level or its manifestations in daily life. To a certain degree, ethical consideration is determined by individual preferences; everyone is capable of using his or her personal preference in assessing an action's right and wrong. As a result, every action may be justified from the perspective of consequentialism, deontology, virtue ethics, or perhaps other perspectives. The problem of ethics subsequently appears when individual moral assessment turns out 
to contradict general values prevalent in the society. The inconsistency between personal virtue and public virtue has, thus, become the essence of ethical problems in the public sector (Thompson, 1992, p. 254).

\section{Ethical Dilemmas in the Public Sector: Features and Manifestations}

Public sector ethics basically involves the application of basic ethical principles on the conducts of government bureaucratic personnel in carrying out their main tasks and functions as a public servant. Discussions on government functions in public sector management become vital as public sector ethics originates from the definition of those governmental functions. A better understanding of public sector ethics can be obtained comparing features of public sector management with that of private sector management.

The characteristic difference between public and private sector management includes at least three things (Allison as cited in Shafritz \& Hyde, 1997, p. 383-400). Firstly, decisions or policies in the private sector are commonly aimed at maximizing profit, whereas public sector policies prioritize public services and fulfillment of public interests. Hence, effectiveness and efficiency are sacred principles in private management while public sector management involves considerations of values other than effectiveness and efficiency more, such as principles of justice, equity, and accountability. Secondly, the main task of an employee in the private sector is to serve the company's interest and to have a limited response to the company's stakeholders.
Meanwhile, public sector management involves the use of public resources and requires public trust in order to achieve institutionalization of public accountability. Therefore, the main function of government personnel is to serve societal interests based principles of public accountability and responsibility. Thirdly, a striking feature of public sector management is the politicization of the bureaucracy and political activities susceptible to violating ethical principles.

These characteristic differences have an implication on the difference of ethical considerations within the public and private sector management, as presented in Table 1. Such characteristic differences subsequently have serious implication on the forms of ethical dilemmas that commonly occur in the public sector.

The dilemma may be defined as " a valid argument which concludes with a choice between two equal alternatives" (Harding, 1985, p. 45). A person is said to be in a dilemmatic position when confronted with a situation compelling them to choose one of the two available options while concurrently unable to choose both. The story of the prisoner's dilemma is an illustration that properly describes the essence of a dilemma with its nature of the zero-sum game. The solution to a dilemma involves two main issues: how to determine the validity of an argument and how to assess which argument is more valid than the other.

The ethical dilemma may happen when "... there is a perceived conflict between two or more ethical principles, such as respect of confidentiality

Table 1.

Ethical Climate

\begin{tabular}{|c|c|c|c|}
\hline \multicolumn{4}{|c|}{ Level of Reference } \\
\hline Ethical Criteria & Person & Company & Society \\
\hline Egoism & Self-interest & Company interest & Efficiency \\
\hline Benevolence & Friendship & Team interest & Social responsibility \\
\hline Principle & Personal morality & Rules and operating procedures & Laws and professional codes \\
\hline
\end{tabular}

Source: Fritzsche (2006, p. 94) 
versus responsibility to the public good" (Leone, Stame \& Stagle, 2016, p. 152). Public sector management is inseparable from such problem of an ethical dilemma. The decision-making process in public sector management involves numerous ethical considerations in order for the decision made to be considered 'right,' and this is not unlike the choice of argument regarded to be 'valid' requiring ethical principles as the major consideration. Ethical principles are even regarded as the highest tier of moral development that can be used in the decisionmaking process.

Ethical dilemma in the public sector has at least five characteristics (Hodge, Anthony \& Gales 1996, p. 67) that are (1) actions taken have extended consequences; (2) decision maker is always confronted with choices and must carry out a selection process to produce the bestconsidered decision; (3) outcome produced from an action is complex in nature; (4) consequences of actions are often immeasurable and difficult to predict; and (5) decisions made have personal implications and impact on others or the society. The central issue in the five characteristics of ethical dilemma above is the exercise of moral judgment in making the best-considered decision through the bestconsidered means.

Generally, the ethical dilemmas faced by government employees are brought about by existing conflict of values and conflict of roles. Conflict of values includes the clash between individual values and public values (Meriade, 2016 , p. 2). Whereas conflict of roles leads to a conflict of interests as a logical consequence of expectations to the performed roles. These roles include (1) government employees as a person or individual; (2) government employees as a patron to their family and primordial group; and (3) government employees as government personnel.

Thompson (1987) accurately summarized the essence of ethical dilemma in the public sector as follows:

\begin{abstract}
"The ethical conflicts that officials confront arise from two general characteristics of public office: it's representational and its organizational nature. Officials act for us, and they act with others. The first characteristic generates conflicts between principles of action; the second, conflicts between principles of responsibility"(p. 4).
\end{abstract}

Ethical dilemma occurs at the very least in three given situations. First, a situation in which friction between one's interest as an individual and as a government employee exists. Egoism is observed as the main cause of conflict because humans tend to show egoistic rather than altruistic values. Most people are inclined to be more interested in their own well-being rather than attending to others' well-being, and this causes what is known as the conflict of interhuman desires. Practices of corruption aimed at enriching oneself is a primary example of the ethical dilemma that is rooted in this interhuman conflict of desires. As presented in daily mass media coverages, a number of corruption techniques commonly employed to enrich oneself, among others are (1) carrying out fictitious projects; (2) having official business trips that are actually unnecessary but merely for the sake of obtaining travel allowance; (3) purposely creating convoluted bureaucratic procedures and expecting to gain money through bribery; (4) using regional or state government facilities for personal purposes; (5) manipulating financial statements.

The activities of organizational politics also contribute to this inter-human conflict of desires. Vigoda (2001) asserts that “... organizational politics is considered a natural means by which an employee can gain advantages and achieve personal interests in the workplace" (p. 1551). Activities of organizational politics lead to dilemmas because politics involves the exercise of power that is often contradictory to principles of ethics (Krisnajaya, 2006, p. 
56). Occurring political activities involve means-ends logic wherein the ends justify the means of achieving said ends-a perspective entirely supported by "politics of dirty hands" activists (Shugarman, 2000, p. 1). Egoistic actions taken are usually manipulation, discrimination, alienation, scapegoating, and character assassination.

Second, government employees particularly political and structural officials do not only assume the role as a superior to their subordinates but also as a patron in their family circle-nuclear or extended family - and in their primordial community. In this context, a person engages in corruption, collusion, and nepotism (KKN) not merely to fulfill household needs but also to help boost the well-being of their extended family and primordial community. This issue becomes more complex when members of the extended family and primordial community have excessive expectations on the patron; the prevailing general assumption is that government officials wield substantial financial resources and have the authority to access those financial resources to fulfill their expectations. The phenomenon of "titipan" (an individual entrusted to the patron) in the recruitment process for civil servant applicants (CPNS) is one of the government officials' means of assuming their role as "patron" while concurrently maintaining the patronage network that they benefit from.

The phenomenon of quid pro quo politics following the general election of the regional head is another form of such ethical dilemma. The contribution of the campaign team that is basically backed up by members of the extended family and primordial community is by no means free of charge. The elected regional head has the "moral obligation" to repay the services provided by the supporters. The means pursued in repaying their services may vary, ranging from nepotism in the recruitment of CPNS, favoritism in occupational promotion in the regional bureaucracy, up to collusion in providing the winning tender for regional government projects.

Third, ethical dilemmas also arise when conflicts rooted in the roles and functions as government employees occur. "Ethical dilemmas in management are pervasive; both in appearance and reality they are part of being $a$ public servant" (Bowman \& Williams, 1997, p. 522). It is this very issue occurring in the Indonesian context wherein the State Civil Apparatus (Aparatur Sipil Negara - ASN) holds two roles as a servant of the state and a servant of the people. The central issue is to whom is the state apparatus responsible and accountable? Are they responsible to their superiors or to the public? On the one hand, the state apparatus' responsibility to their superiors requires them to obey the decisions made by the state. On the other hand, public accountability requires them to prioritize public service rather than being a slave to the government's transient interests. Government personnel is trapped in a dilemma when they are forced to choose between maintaining loyalty to their superiors and prioritizing the principle of public accountability. Such ethical dilemma becomes progressively rampant within a societal structure that bears a strong "patron-client" culture.

Ethical dilemmas also commonly occur in the public policy-making process. Decisions categorized as being unethical are often necessary, and in some cases, they are in fact common place whereby these unethical decisions become 'legal.' This, according to Frederickson (1997), is one of the main issues in "policy ethics"(p. 175). As an example: the state has the obligation of providing protection and safety to its people. However, there are situations that force government elites to sacrifice the lives of some for the sake of national defense and security.

The various forms of ethical dilemma above would eventually lead to decisions or actions categorized as ethical and unethical. 
The decision-making process or the final assessment regarding the decision made will be much determined by the ethical perspective employed, whether it is deontology, consequentialism, or virtue ethics. Every action or decision made may seemingly be justifiable by using one of those ethical perspectives. Government personnel who engage in corrupt practices, for example, may argue that corruption was carried out due to the state's incapability in providing welfare to its apparatus. Corruption would seem to be a logical consequence brought about by the errors of the state. An even more horrendous state is when the mentality proliferating among government personnel is "if we don't do it (corruption), then we won't get our share (of prosperity)." Such mentality is not unexpected when corruption in the bureaucracy has become pathological, wherein corruption is conducted systemically in massive numbers.

The dilemmatic condition confronted by regional heads who were elected through the regional head election (pilkada) is no less complicated. In addition to the demand of assuming their role as a patron to the family and primordial group, the elected regional heads are "forced" to conduct political corruption due to the shortcomings inherent within the prevailing pilkada system. It is no secret that the regional head candidates participating in the pilkada process in Indonesia require a substantial amount of fund and in some cases, it had even exceeded normal standards. It is said that political corruption happens as a logical consequence of the pilkada system's own imperfection. Unethical actions conducted post pilkada are, thus, not an option but a given inevitability. Within such context, the use of deontological and virtue ethics considerations would surely loose their charm.

Based on the above elaboration, the decision made by an individual in addressing the ethical dilemma one is confronted with shall never be separated from the clash of argumentation-or just to be exact-that underlies that decision-making process. The subsequent question would then be: should moral assessment or ethical consideration be handed back to the personal domain or should it be integrated into a system of conduct that is institutionally agreed on and collectively obeyed?

\section{Institutionalization of Ethical Principles in the Public Sector}

Efforts of finding a way to overcome ethical dilemmas in the public sector basically depend on how ethical dilemma is defined. The essence of the various forms of ethical dilemma lies in the conflict between personal virtue and public virtue. Thus, the ethical dilemma in the public sector may be subdued-or moderated to be precise-by formulating a series of common values that are socially legitimate, which means that they should be aligned with the normative structure of the prevailing social-political system. The principles generated through this consensus are expected to be able to resolve the issue of ambivalence pertaining to assessing what is considered as right conduct. These principles would subsequently be made into a mutual reference or manual of conducts. One of the forms of this manual of conducts is a code of ethics or what Nietzsche referred to as the "language of good and evil" (Fukuyama, 1996, p. 35).

Once discourse on ethics and its relevant issues have permeated to the dialogical domain on a global scale, the efforts of resolving ethical dilemma issues through the formulation and implementation of ethical principles would also be manifested into a global movement. The implementation of such ethical principles includes, among others, in-service ethical training, whistle-blowing, ethics legislation, and code of ethics (Luk, 2012, p. 363).

Principles relating to work ethics for government employees and officials in the United States of America, for instance, contain fourteen themes that are stipulated in Executive 
Order 12674 and some of its stipulations are strengthened by the 1992 Appropriations Act. Two basic issues that are regulated concern the performance of government employees' duties and use of government facilities. This Executive Order regulates the employees not to use public office for private gain, not to hold financial interests that are in conflict with their duties and authorities, not to use information directly related to their position for private interest, and not to utilize their position for accepting gifts (Rose-Ackerman, 2010, p. 106).

In 1998, OECD launched a Recommendation on Improving Ethical Conduct in the Public Sector for developing government ethics with basic principles that, among others, are: (1) code of ethics should be clear; (2) code of ethics should be placed within a legal framework; (3) there should be an accountability mechanism in government institutions; (4) the decision making process should be transparent and accountable: (5) government employees should act ethically; (6) public officials should present ethical behavior; and (7) there should be an adequate sanction mechanism to address violations or manipulations (deVries, 2002, p. 317).

Makrydemetres offers an ALIR model as basic principles that should be adopted to overcome ethical dilemma issues in the public sector. This model is meant as: "the advanced set of fundamental principles or criteria that integrate and rearrange the process of dealing with ethical dilemmas in public administration" (Makrydemetres, 2002, p. 255).

\section{Figure 1.}

ALIR model of imperatives: A, democratic Accountability; L, principle of Legality and the rule of law; I, professional Integrity and autonomy; and R, Responsiveness tocivil society

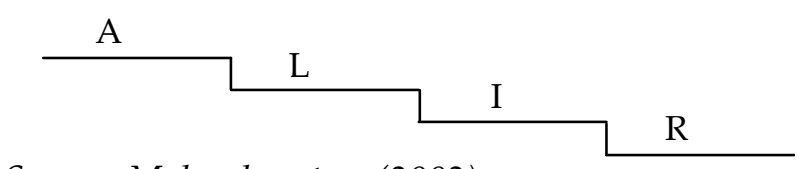

Source: Makrydemetres (2002)
As seen in Figure 1, the ALIR model integrates principles of Accountability, Legality, Integrity, and Responsibility in response to ethical dilemmas occurring in the context of democratization and implementation of good governance in the public sector. This model definitely needs to be further developed particularly regarding its operational opportunities. A code of ethics ideally includes reference principles that are both disciplinary and aspirational being classified from the lowest to the highest standard (Sampford as cited in Preston, 1994, p. 15). Each basic principle should be further elaborated into more specific ethical principles. For instance, the principle of professional integrity may be elaborated into trustworthiness, reliability, and openness (Greenberg \& Baron, 2000, p. 448). Wilding humorously said that "two spoonsful each of honesty, tenacity and obedience; and one spoonful of humility are the ingredients that make an ethical administration" (deVries, 2002, p. 309). The entirety of these ethical principles is then integrated into government institutions in the form of formal rules as law and regulation or informal directives as convention, norms, and code of ethics.

The government of Indonesia regulates the development of esprit de corps and code of ethics for Civil Servants (Pegawai Negeri Sipil - PNS) by using Government Regulation of the Republic of Indonesia No. 42 the year 2004. The PNS code of ethics is defined as "a guideline of attitude, behavior, and conduct for PNS in carrying out their duties and daily life interactions." This code of ethics consists of ethics in statesmanship, social ethics, organizational ethics, personal ethics, and ethics in mutual interaction with fellow PNS. Some of the ethical values covered in the code of ethics, among others, are: (1) to be responsive, open, honest, accurate, and punctual in conducting every state policy and program; (2) to be obedient and compliant to standard operating and working procedures; (3) to provide quick, accurate, open, and fair non-discriminatory 
services; (4) to be honest and open while not providing invalid information; and (5) to avoid conflicts of personal or group interests.

Concerning the feasibility of implementing a code of ethics to overcome ethical issues, it is interesting to compare the perspective of modernity and postmodernity. Bauman, one of the postmodern thinkers, considers a code of ethics as a modern product that should be rejected as it is choke full of contradictions and ambivalence (Ritzer, 2004, p. 278-282). According to Bauman, there is actually no good or evil individual; there are only individuals who are morally ambivalent. Hence, Bauman is of the opinion that code of ethics would not help much in improving morality, which is basically contradictory and ambivalent. Such claim is subsequently known as privatized morality which bears implication on the need for an ethical system rising from within the human self-based on principle "available for others before being able to be with others"' (Ritzer, 2004, p. 280). The implication of Bauman's critique is that ethical issues are handed back to the personal domain, so that code of ethics becomes unnecessary.

Regardless of Bauman's criticism, a number of study results show that code of ethics remains effective as a means to cultivate ethical behavior and commitment in state institutions (Bowman \& Williams, 1997, p. 521; Kumasey, Bawole \& Hossain, 2017, p. 72). However, making a code of ethics alone is not enough as a compilation of these ethical principles - as claimed by proponents of ethics virtue-would only be effective for people of wisdom with ethical character, but it that would not be the case with people who have yet retained a quality ethical personality. Hence, the code of ethics should be institutionalized to be more effective.

Institutionalizing ethical principles means putting ethics as the élan vital within the social institution as a whole. The code of ethics, for instance, should be integrated into a system of action that covers standard values and norms serving as a reference for everyone's conduct. As Scott (2001) mentioned "a system of action was said to be institutionalized to the extent that actors in an ongoing relation oriented their actions to a common set of normative standards and value patterns"'(p. 15). Even so, we need to keep in mind that code of ethics is a flexible and revisable instrument: "code of ethics does not replace ethical reasoning, but it is always accompanied by ethical reflection instead" (Bertens, 2011, p. 299).

Institutionalization of public sector ethics basically involves the integration and revitalization of ethical principles in public institutions. Institutionalization of ethical principles may be carried out by using two approaches, namely the internal and the external approach. The preference of using these approaches are by no means mutually exclusive, but it is more a choice of priority. Ideally, both approaches are employed simultaneously as both mutually complement each other rather than being a substitute for the other. Makrydemetres (2002) emphasizes the importance of internal approach rather than utilizing coercive approaches that are enforced through legal instruments:

"Ethics is about choice, the choice of the good, which is then habituated in actual conduct. A further implication of that is ethics cannot be conceived of as a matter of punishment and rewards, but rather as a matter of voluntary choice of the good, which is then consistently exhibited in one's conduct"(p. 253).

The main strategy of internal approach is habituation or familiarization: "as Aristotle points out in the Ethics, moral virtue, unlike intellectual virtue, is learned through habit and repetition, such that initially unpleasant activities eventually become either pleasant or, at any rate, less unpleasant" (Fukuyama, 1999, p. 220). This approach may be prompted by exploring and cultivating noble values of national heritage as 
a basis for developing ethical principles. Porter (1990) has shown that the glory of a nation is determined by the people's superior work ethic, and superior work ethics is rooted in ethical principles that have steadily been inherited over time. The Samurai tradition in Japan and Confucianism in China are a code of conducts sources that have led the two nations to their current glory.

The National Character Development Policy implemented in the era of Susilo Bambang Yudhoyono's presidency, and the Mental Revolution Policy in the era of Jokowi's presidency emphasize Indonesian government's preference for the use of the internal approach. The rationale underlying these policies is that ethics should be institutionalized with a cultural approach. The strategy of national character development and mental revolution should be more focused on dissemination efforts, habituation, and culturization of ethical values with human personalities as the unit of analysis. The aspired characteristics, among others, are honest, polite, tolerant, humble, sympathetic, sportsmanlike, discipline, persistent, and responsible. These are the characteristics expected to be inherent within the self of every Indonesian citizen, particularly state civil apparatus and political officials of the state.

The institutionalization of government cultural values dubbed SATRIYA in the Yogyakarta Special Region Administration serves as an actual model of institutionalizing ethical principles by using internal approach and involving a series of activities that includes dissemination, training, and habituation (Sulistiyani et al., 2017). Institutionalization of the SATRIYA government culture-regulated through the Yogyakarta Special Region Gubernatorial Regulation No. 53 Year 2014 on the Guideline for the Implementation of Government Culture - is meant to: (1) provide a guideline for Regional Work Unit (Satuan Kerja Perangkat Daerah - SKPD) to carry out and implement noble values of government culture in their work environment; (2) provide description pertaining to indicators of government cultural values into daily attitude and behavior (code of conducts) when conducting one's duty or when living their daily life; and (3) accelerate change of mindset, attitude, and behavior of State Civil Apparatus in the Yogyakarta Special Region so that they are aligned with the values of SATRIYA government culture. The most valuable lesson learned from Yogyakarta's experience is the true importance of habituation process and model leadership to successfully institutionalize ethical principles in public bureaucracy.

\section{Conclusion}

Ethical dilemmas in the public sector are essentially caused by two main factors, namely, (1) the ambivalence of ethical implementation and definition in the public sector; and (2) the conflict between personal virtue and public virtue. To resolve ethical dilemmas reconciliation is required both at the theoretical and implemental levels. Institutionalization of ethical principles in the public sector is one of the means that can be carried out to accommodate such reconciliatory efforts.

It is necessary to underline the argument that the institutionalization of ethical principles in the public sector should be coupled with law enforcement. Legal instruments in the form of administrative law remain necessary to ensure effectiveness and coerciveness of ethical principles as a code of conducts for government employees in carrying out their duties and functions. A series of regulation that covers sanction mechanism needs to be enforced to minimize potential unethical conducts and maladministration in public management.

No less important is the effort of improving effective and exemplary leadership. A leader should be a role model, that is a figure that is capable of controlling one's attitude and actions, particularly in maintaining the consistency 
between attitude and actions along with the prevailing ethical principles. A leadership that prominently reveres ethical principles is expected to inspire and set an example so that it would accelerate the process of institutionalizing ethical principles in public institutions in its entirety.

\section{References}

Alkadry, M. G., Blessett, B. \& Patterson, V. L. (2015). Public administration, diversity, and the ethic of getting things done. Administration \& Society, 49(8), 1191-1218. doi:10.1177/0095399715581032

Baggini, J. (2003). Lima tema utama filsafat: Filsafat pengetahuan, filsafat moral, filsafat agama, filsafat pikiran, dan filsafat politik (Trans). Jakarta: Penerbit TERAJU.

Bertens, K. (2011). Etika. Jakarta: PT Gramedia Pustaka Utama.

Bowman, J. B \& Williams, R. L. (1997). Ethics in government: from a winter of despair to a spring of hope. Public Administration Review, 57(6), 517-18. doi: 10.2307976963

Caiden, G. E. (1991). Administrative reform comes of age. New York: Walter de Gruyter.

DeVries, M. S. (2002). Can you afford honesty? A comparative analysis of ethos and ethics in local government. Administration E Society, 34(3), 309-334.

Frederickson, H. G. (1997). The spirit of public administration. San Francisco: Jossey-Bass Publishers.

Fritzsche, D. J. (2006). Business ethics: A global and managerial perspective. New York: The McGraw-Hill Companies, Inc.

Fukuyama, F. (1999). The great disruption: Human nature and the reconstitution of social order (Trans.). New York: The Free Press.

Fukuyama, F. (1996). Trust: The social virtues and the creation of prosperity (Trans.). New York: Free Press Paperbacks.

Gilman, S. C \& Lewis, C. W. (1996). Public service ethics: A global dialogue. Public Administration Review, 56(6), 517-24.
Grace, D \& Cohen, S. (1995). Business ethics: Australian problems and case studies. Oxford: Oxford University Press.

Greenberg, J \& Baron, R. A. (2000). Behavior in organizations $3^{\text {rd }}$ edition. New Jersey: Prentice-Hall, Inc.

Harding, C. G. (ed). (1985). Moral dilemmas: Philosophical and psychological issues in the development of moral reasoning. Chicago, Illinois: Precedent Publishing Inc.

Hodge, B. J., W. P. Anthony \& L. M. Gales. (1996). Organization theory: A strategic approach. New Jersey: Prentice-Hall International.

James, C. (2003). Economic rationalism and Public sector ethics: Conflicts and catalysts. Australian Journal of Public Administration, 62(1), 95-108.

Kattsoff, L. O. (2004). Pengantar filsafat (Trans.). Yogyakarta: Tiara Wacana Yogyakarta.

Krisnajaya, I M. (2006). Kepemimpinan dan politik dalam organisasi. Jurnal Politik dan Manajemen Publik Interaksi, 1(1), 47-61.

Kumasey, A. S., Bawole, J. N. \& Hossain, F. (2017). Organizational commitment of public service employees in Ghana: Do codes of ethics matter? International Review of Administrative Sciences, 83(1S), 59-77.

Leone, L., Stame, N. \& Stagle, T. (2016). Exploring ethical issues and conditions for institutionalizing evaluation in the public sector. Evaluation, 22(2), 149-167.

Luk, S. C. Y. (2012). Questions of ethics in public sector management: The case study of Hong Kong. Public Personnel Management, 41(2), 361-378.

Makrydemetres, A. (2002). Dealing with ethical dilemmas in public administration: The 'ALIR' imperatives of ethical reasoning. International Review of Administrative Sciences, 68, 251-66.

Meriade, L. (2016). The characterisation of the values of public ethics: Application to territorial public management in the 
province of Guangxi (China). International Review of Administrative Sciences, 0(0), $1-21$.

Peraturan Pemerintah Republik Indonesia Nomor 42 Tahun 2004 Tentang Pembinaan Jiwa Korps dan Kode Etik Pegawai Negeri Sipil.

Ping, A. C. (1996). An organic perspective on organisational ethics. Management (North Sydney), 17-19.

Porter, M. (1990, March 12). Why nations triumph. Fortune, 94-108.

Preston, N. (2001). Understanding ethics. Leichhardt, NSW: Federation Press.

Preston, N. (1994). Ethics for the public sector: education and training, Federation Press, Annandale, NSW.

Ritzer, G. (2004). Teori Sosial Postmodern (Trans.) Yogyakarta: Kreasi Wacana.

Rose-Ackerman, S. (2010). Korupsi dan pemerintahan: Sebab, akibat dan reformasi (Trans.), Pustaka Sinar Harapan, Jakarta.

Russell, B. (2007). Sejarah filsafat barat dan kaitannya dengan kondisi sosio-politik dari zaman kuno hingga sekarang (Trans.). Yogyakarta: Pustaka Pelajar.

Schmandt, H. J. (2002). Filsafat politik: Kajian historis dari zaman Yunani Kuno sampai zaman modern (Trans.). Yogyakarta: Pustaka Pelajar.

Shafritz, J. M \& A. C. Hyde (eds). (1997). Classics of public administration. Forth Worth: Harcourt Brace College Publishers.
Scott, W. R. (2001). Institutions and organizations. California: Sage Publications Inc.

Shomali, M. A. (2001). Relativisme etika: menyisir perdebatan hangat dan memetik wawasan baru tentang dasar-dasar, oralitas (Trans.). Jakarta: Serambi.

Shugarman, D. P. (2000, April 28). The work of dirty hands. The Australian Financial Review.

Stewart, D. W. (1991). Theoretical foundations of ethics in public administration: Approaches to understanding moral action. Administration \& Society, 23(3), 357-74.

Sulistiyani, A. T., Krisnajaya, I. M., Sunartiningsih, A., Yuliani, K., \& Yuliana, M. (2017). Strengthening good governance through institutionalization of SATRIYA codes of conduct: A lesson from Yogyakarta Special Region. Proceeding Advances in Social Science, Education and Humanities Research. Makassar: 427-431.

Thompson, D. F. (1992). Paradoxes of government ethics. Public Administration Review, 52(3), 254-259.

Thompson, D. F. (1987). Political ethics and public office. London: Harvard University Press, Cambridge, Massachusetts.

Vigoda, E. (2001). Reactions to organizational politics: A cross-cultural examination in Israel and Britain. Human Relations, 54(11), 1483-1518. 